\title{
Coping in medieval prisons
}

\author{
G. GELTNER*
}

ABSTRACT. Based on archival research in several Italian city-states, this article examines medieval prison life, its attendant pains, and inmate coping strategies by substantially engaging the variety of scholarship on modern incarceration. It demonstrates the limited degree to which current hardships overlap with those of earlier forms of captivity, and underscores the diversity of inmates' social positions in both eras. Medieval prisoners were marginalized, but they avoided social liminality (a major present-day risk) largely thanks to their visibility, accessibility, and frequent interaction with free society.

\section{INTRODUCTION}

Modern incarceration is a complex penal measure. Losing one's freedom is only one of many hardships, which range from material poverty and increased exposure to violence and substance abuse, to the deprivation of normative sexual relations, autonomy, and security, to the severing of social ties. Sociologist Gresham Sykes, in his pioneering study of US prison life, defined and explicated these 'pains of imprisonment', and argued that they dynamize the society of captives 'as a system of action'. Sykes's followers have since refined his methodology and conclusions, demonstrating that the pains of incarceration and inmate responses to them vary enormously, not only between institutions but also among individuals and throughout their particular prison careers. ${ }^{2}$

Diversity of pains cuts across eras as well. For instance, strict routines are a hallmark of modern 'total' institutions, where 'power is articulated directly onto time'. ${ }^{3}$ This is especially true for those inmates who, prior to their internment or institutionalization, led an uninhibited lifestyle, and for whom the regimentation of time may be the source of great distress. Medieval inmates, on the other hand, had no formal daily schedule.

\footnotetext{
* Lincoln College, Oxford.
} 
Further, although medieval prisons' punitive function was often greater than is commonly recognized, they mostly served as places of detainment and for the coercion of debtors. Accordingly, such facilities tended to be small, lengths of incarceration there brief, and the inmates' socioeconomic background (especially in the case of debtors) average rather than low, in sharp contrast to present-day realities. ${ }^{4}$

Yet perhaps the greatest and most telling difference between modern prisons and their medieval predecessors is the degree to which the latter's residents remained integrated with free society. For in contrast to the present ruralization of penitentiaries or the attempt to camouflage them as downtown office buildings, medieval prisons served as proud symbols of a polity's autonomy and as such featured prominently in the civic landscape. As cogs in local machineries of justice, these facilities could constitute independent buildings like Florence's Le Stinche, London's Fleet, and Paris's Châtelet, or (more commonly) occupied wings within government compounds such as the Italian palazzo comunale or the German Rathaus. In either case they were wont to be physically central spaces which habitually flanked the city's main political square. ${ }^{5}$

Prisons' central location deeply affected their inmates' welfare, for even in the commotion of urban life prisoners were hard to ignore: the parish church of San Simone in Florence flanked Le Stinche's southern wall; in Bologna, fifteen artisans and merchants rented shops near the lower prison; a high mortality rate among Sienese inmates and the squalor of the existing facilities moved several citizens to petition for a new prison; and in 1395 a certain Gaillart took pity on a desolate woman thrown into the king's prison in Le Puy, France, on the charge of murder. After failing to convince the jailer to better her conditions, Gaillart, accompanied by a group of local men, stormed the place, dragged the jailer outside, and severely beat him. ${ }^{6}$ The public eye was always watchful.

Visibility, moreover, was accompanied by accessibility. Basic arrangements of medieval prison life relied on routine external support, so much so that there was no formal restriction on importing personal items such as candles, bedding, and writing materials: if there was a black market in medieval prisons, nowhere does it emerge from the available sources. Indeed, such contraband would have been nearly impossible to monitor given the volume of human traffic pouring into and out of these facilities. Public officials, clergymen, friars, confraternity members, lawyers, notaries, businessmen, creditors, service givers, and family members - all encountered inmates on a daily basis. ${ }^{7}$

Incarceration in the middle ages, in fine, was only a semi-exclusive - and ipso facto a semi-inclusive - measure. Medieval prisons were not total but 'proto-total' institutions, and their inmates were marginal, not liminal 
figures; that is, they were perched between social exclusion and inclusion, not written out of social memory. ${ }^{8}$ The distinction is significant: unlike liminals, marginals are essential for the maintenance of social cohesion since they define a group's border between normality and deviancy. ${ }^{9}$ In other words, marginals and deviants play an active role in society, while liminals forget and are forgotten by it. This palpable difference is borne out by comparing medieval to modern inmates.

All this is not to dismiss the conclusions, let alone the methodologies, of modern prison observers. Quite the contrary: the present article underscores the relevance of modern sociology and psychology, forensic psychiatry, corrections literature, and autobiographical accounts to the historical investigation of pre-modern, proto-total institutions. To do so, I first survey medieval inmates' characteristic pains and available responses, and then move to explore prisoner violence and dissidence as particular strategies of coping, and the degree to which such activities were allowed by the staff. Next, by focusing on the role of inmates' access to the outside world (and vice versa), I argue that the distinction between social marginality and liminality characterizes the medieval and modern prison experiences, respectively. It is the social accountability attendant upon marginality that underlies the relative tolerability of medieval prison life.

\section{PAINS, DIVERSIONS, RESPONSES}

Although both a rigid routine and its total absence can create monotony, sheer boredom seems to have been medieval inmates' share. Broadly speaking, these men, women, and (occasionally) children had scarce access to either labour or formal programming. Their diversions, moreover, were scarce: reading material was hard to come by, space for recreational activities limited, alcohol mostly prohibited, drugs nonexistent, and prostitutes rare. Financial and legal affairs could occupy some of a prisoner's time, but these would soon be finished and seldom guaranteed even an occasional leave. Begging outside the prison walls to help pay for one's incarceration (as was the norm in this period) was only intermittently allowed, even before the practice was abandoned in favour of employing penitential friars. There were, to be sure, daily masses and bread distributions, weekly sermons and inspections, and the city's liturgical cycle, which the inmates could follow - albeit vicariously - during major feasts or victories. But all these only briefly interrupted an otherwise humdrum existence.

Prison life, then as now, was a struggle, and in facing their predicaments medieval inmates had limited options. The few who could read and wrote. 
At Le Stinche, Florence's municipal prison founded c. 1300, literate prisoners could occasionally earn some money by copying manuscripts and account-books. Others wrote about their personal experiences. Ser Jacopo del Pecora of Montepulciano, who in 1395 had already been imprisoned at Le Stinche for fifteen years, composed letters and poetry in terza rima. While incarcerated in the Sienese prisons, the burlesque poet Burchiello (1404-49) wrote, 'I have no water except for the roof drops, / Nor the sun if it is not checkered. / I can't have bread unless of affliction; / If I was ever happy, let evil kill me.' The satirist Dino di Tura, who in 1343 languished for several months at Le Stinche, wryly declared that 'the prison is the best place in the world ... its doors are open to anyone'. And Adoardus de Assisi, vicar to the papal legate in Bologna, where he was imprisoned in 1362, describes a fate worse than death: 'Since Fortune so / Cruelly cast me down, / I pray to you, Death, earnestly, / To end these sorry tears.' But, to repeat, these are rare exceptions: inmates seldom recorded life in captivity. ${ }^{10}$

Observations by outsiders are equally scarce but no less illuminating. A Dominican friar passing through Venice in 1484 noted, not without wishful thinking, that local inmates were perfectly divided along external social fault-lines, with their attendant pursuits: the merchants played and received visitors, the artisans plied their trades, and the poor cried for mercy. ${ }^{11}$ Venetian prisoners also passed their time decorating their cells with graffiti: they carved day-charts, composed lamentations and prayers, recorded deaths, and occasionally drew objects such as buildings, ships, and human figures (see Figure 1). ${ }^{12}$

Physical remains and written accounts reveal that apart from such relatively harmless pastimes, inmates also pursued a range of forbidden activities. They blasphemed and sang dirty songs, struck up illicit conversations with female inmates, conspired to escape, and plotted revenge against personal enemies or the government. Some of them engaged - and at times forced others to engage - in homosexual or heterosexual intercourse. $^{13}$

Yet by far the most common distraction among inmates seems to have been gambling, an activity banned due to its potential for accruing further debt, its association with violence, and, no less importantly, its blasphemous nature. Gambling may have been popular for any number of reasons. It was easily arranged and dissolved, it created an immediate diversion, and it promised (falsely, for the most part) to improve one's influence and material conditions. But perhaps the main attraction of gambling was its familiarity as a common and equally abhorred activity in the free world: however briefly, gambling transported its practitioners into pseudo-liberty. ${ }^{14}$ 


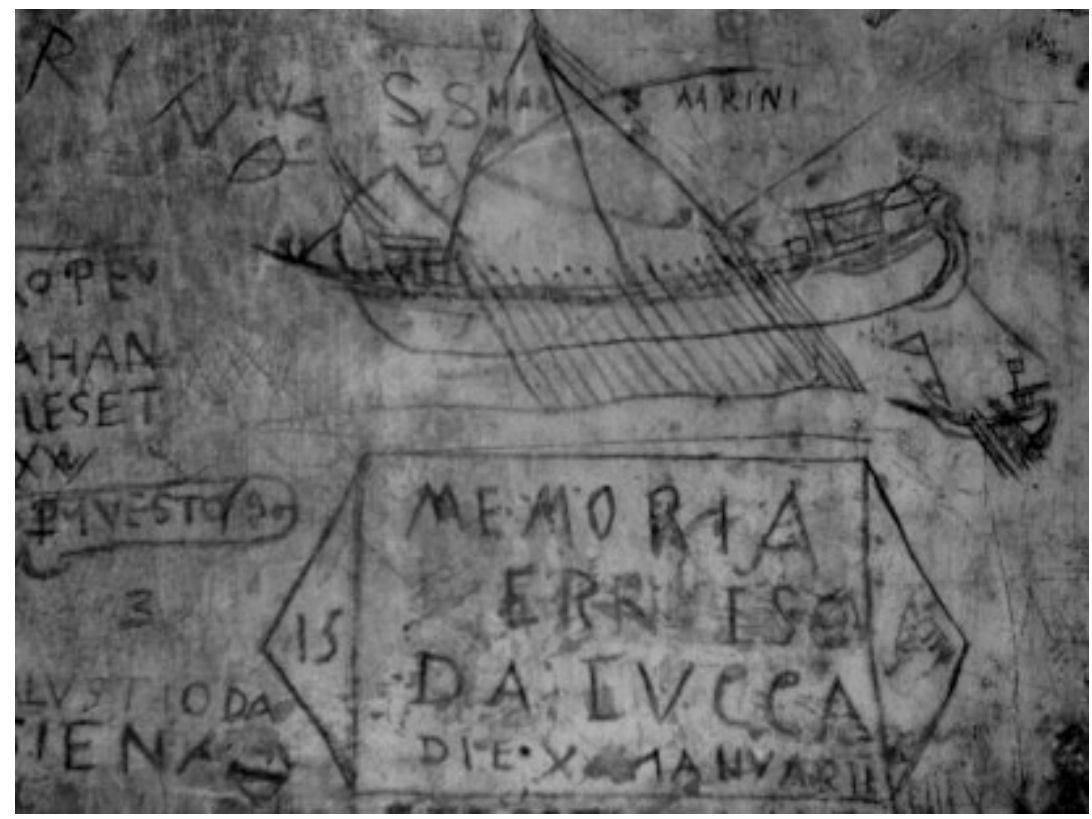

FIgURE 1. Inmate graffiti from the Pozzi prison, Venice (undated). (Photo by the author, by permission of the Director of the Musei Civici di Venezia.)

Physical harassment was prevalent as well. Responding to repeated cases of aggression at Le Stinche, the Florentine magistrates ordered in 1355 that any inmate who injured another was to be fined and forced to pay the condemnation within eight days, or else have an arm amputated. ${ }^{15}$ Even if the regulation was enforced, however, its deterring power was weak. For inmates turned on one another all the same: a day after Biagio di Filippo struck Ubicino di Gentile 'with an empty hand', the latter retaliated by stabbing Biagio with a knife; Naso di Baldo of San Felice confessed to a sexual assault; Jacopo di Giovanni injured Giovanni di Lapo by turning his bed over while the latter was sleeping; and so it goes. ${ }^{16}$ It is against this background that we can perhaps begin to understand the fear of a young Venetian named Marco, who volunteered to remain three years behind oars in the galleys rather than spend six months behind bars. ${ }^{17}$ But evasion was unlikely, making recourse to violence and other forms of dissidence a more pertinent coping strategy.

\section{VIOLENCE AND DISSIDENCE}

Interpretations of modern inmate violence - physical, sexual, verbal, and emotional-abound. And whether it is seen as a sinister aspect of an 
indigenous culture or as another arena for ensuing struggles outside the prison walls, such activity is commonly agreed to be endemic. ${ }^{18}$ Our documents lack much of the circumstantial data that would facilitate a responsible investigation of medieval prison violence, at least by modern sociological criteria. The succinct descriptions of such incidents and the murky biographies of ordinary inmates preclude geographical or socioeconomic profiling of either victims or assailants. A prisoner's age, for instance, commonly thought today to influence aggressive behaviour, is rarely documented in the extant sources. Paucity of information likewise prevents any meaningful estimate of the relations between violent behaviour and the length of an inmate's sentence, the time elapsed from one's arrest, or one's potential proximity to release.

One pattern that does emerge, however, is that violence was concentrated almost exclusively within the inmate community. Only on rare occasions, such as during mass riots (usually instigated in the context of external political turmoil), did prisoners assault staff. On 20 August 1322, the Bolognese prison guards lost control over some armed inmates, who forcefully broke the prison gate, and in the upheaval precipitating the expulsion of the Duke of Athens from Florence in 1343, inmates trashed Le Stinche and, shrewdly, destroyed its archive. In neither case, however, were personnel severely injured. ${ }^{19}$

That said, whether or not prisoners perceived themselves as locked in a perennial struggle with their captors is entirely a different matter. Animosity between inmates and staff today is difficult to overstate, yet seldom does it escalate into open physical conflict. This, in turn, is contingent upon the prison's highly controlled environment and the potential repercussions - personal and collective - of such acts. Still, even in the relatively loose environment of medieval prisons, with their open wards and a low guard/inmate ratio, the former were hardly ever hurt. Moreover, there is no record of staff ever being taken hostage or of their featuring as anything but indirect casualties of inmate aggression. This benign neglect was probably intentional, as is argued below, since it facilitated a common coping strategy among inmates, namely, collusion with personnel.

To judge by the multiplying regulations of medieval prisons, inmate dissidence was rising throughout the fourteenth century. In 1349, for instance, the supervisors of Le Stinche were charged with investigating gambling and drinking as typical violations. Yet by 1366 the list of potential offences, as related twice annually in the supervisors' charter, already specified swearing and blasphemy, prostitution, entry into the women's ward, sodomy, illicit contacts with the outside world, and general disregard for prison regulations, including brawling, extortion, 
T A B LE 1

Reported inmate infractions at Le Stinche, Florence (1366-1377)

\begin{tabular}{rcccccc}
\hline \hline & Brawling & Assault & Gambling & Blasphemy & Sodomy & Total \\
\hline 1366 & 0 & 1 & 0 & 0 & 0 & 1 \\
1367 & 0 & 0 & 1 & 1 & 0 & 2 \\
1368 & 6 & 3 & 3 & 2 & 2 & 16 \\
1369 & 0 & 3 & 0 & 0 & 0 & 3 \\
1370 & 1 & 3 & 2 & 0 & 0 & 6 \\
1371 & 2 & 0 & 2 & 0 & 0 & 4 \\
1372 & 4 & 10 & 13 & 1 & 0 & 28 \\
1373 & 2 & 11 & 4 & 0 & 0 & 17 \\
1374 & 0 & 0 & 1 & 0 & 0 & 1 \\
1375 & 1 & 0 & 8 & 1 & 0 & 10 \\
1376 & 0 & 0 & 0 & 0 & 0 & 0 \\
1377 & 0 & 0 & 2 & 0 & 0 & 2 \\
\hline \hline
\end{tabular}

Source: State Archives of Florence, Atti dell'Escutore degli Ordinamenti di Giustizia 129, 148, 156, 269, 280, 298, 314, 324, 333, 350, 365, 373, 389, 407, 416, 429, 442, 454, 477, 489, $501,515,535,538,540,573,575,589-90,609,631,633,647,658,663,674-5,678,690,698$, $712,715,725,728,741,744,754,763,770,785,788,790,826,830,852,874,890,909,922$, $939,955,965,980,985,997,1002,1011,1015-16,1022,1026,1037,1064,1081,1082,1095$, $1097,1099,1111,1115,1129,1133,1147,1149,1161,1175,1185,1188,1204,1222,1224$, $1226,1245,1293,1310,1312,1320,1327-9,1343-4,1354-5,1370,1373,1401,1417$.

and physical assault. ${ }^{20}$ In 1400 the charter further underscored the aggressive behaviour of inmates, who "with angry heart and evil intention [instigate] many and various brawls, disturbances, and attacks, whether with their bare hands or armed with iron, namely, by striking and injuring one another' ${ }^{21}$ Whatever relation such statements bear to prison realities, it is safe to say that inmate dissidence and violence were becoming major concerns.

Partly in response to inmate behaviour, Le Stinche's supervisors were obligated to frequent the prison weekly and conduct interviews with representatives of each ward. While potentially a rich source for assessing inmate infractions and coping strategies, the 108 extant protocols of these visitations, covering the years $1350-1400$, are disarmingly silent. Their full examination yielded the results in Table 1. So far as I know, this is a complete list of the consultable inquests for the period. The witnesses distinguished between a simultaneous brawl ('rissa') and a unilateral assault ('percussio'), even when the latter was followed by a counterassault. With one exception (1099, fol. 13v [11 June 1389]), violent offenses involved male inmates only. Gambling necessarily engaged at least two prisoners, but often involved multiple participants. 
The immediate impression is one of massive underreporting, a problem familiar to any modern student of total institutions. ${ }^{22}$ Only 25 per cent of the extant registers (27 out of 108) document any inmate misconduct: there are no reports of violations between 1350-1365, 1378-1384, and 1391-1400. However, underreporting in this case is not argued solely ex silentio. It is highly unlikely that during a period in which reported infractions were absent (1349-1366), the number of potential infractions to be investigated by the prison's supervisors (as related in their charter) grew due to mere speculations about what went on behind Le Stinche's walls. A plausible, if partial, explanation for such discretion is collusion among inmates and, no less importantly, between inmates and guards.

That inmates wished to avoid further sanctions while still incarcerated is obvious enough. Yet the staff's silent compliance is equally understandable. After all, the supervisors focused on the captors' behaviour just as much as on the captives', if not more so. At Lucca, for instance, urban magistrates insisted on monitoring wardens' conduct and the proper exaction of fees, 'lest inmates be burdened beyond what is meet and due, or some extortion, intolerable iniquity, or injustice be inflicted upon them '. ${ }^{23}$ Furthermore, many of the prisoners' infractions, once discovered, would implicate their guards - if not by the latter's active cooperation then at least through their negligence. Le Stinche was divided into several large wards, all of which were observable from a central court and a watchtower. ${ }^{24}$ In other words, inmates substantially relied on the guards' turning a blind eye to their illicit pastimes, above all gambling but also sexual intercourse and the personal settlement of disputes. In the case of importing prostitutes, staff were no doubt instrumental; in 1369, for instance, Le Stinche's deputy chamberlain was fined 5 lire for allowing an 'unauthorized woman' to enter the compound, probably a euphemism for a prostitute's visit. ${ }^{25}$ And there were other occasions of equally blatant infractions facilitated by staff elsewhere: Venetian guards abused the inmates' unique privilege to purchase duty-free wine, which they apparently sold off; their Parmese colleagues were repeatedly warned against 'escorting' inmates to local taverns; and at least one Luccan warden pocketed the difference between the formal fees and those which he exacted.$^{26}$ In 1306, for unstated reasons, the Modenese guards broke out of prison along with the inmates. ${ }^{27}$

Like their modern counterparts, inmates and staff in the middle ages had a major incentive to keep the reporting of infractions to a minimum. But the similarity ends here. For in implicit return for their cooperation, medieval guards and prison employees enjoyed a lack of hostility from inmates that would be unimaginable today. For not only were personnel rarely victimized despite their relatively low numbers and vulnerability, 
but they could also rely on the inmates' silence regarding their own illicit activities. Only a single complaint against staff abuse can be gleaned from Le Stinche's available records, when four inmates denounced the prison treasurer for allegedly miscalculating the fees they owed. ${ }^{28}$ Otherwise, most staff violations emerge in the context of escapes, and it is small wonder that urban statutes commonly held staff guilty in such events, and not merely by association. ${ }^{29}$ In fine, the seemingly high number of infractions reported above for the years 1368,1372 , and 1373 is not necessarily anomalous. Indeed, it is likely that these figures approximate and perhaps even underestimate the typical rate of infractions.

\section{DISSIDENCE AND IDENTITY}

If medieval prison violence differs from parallel modern phenomena in being almost exclusively intra-inmate, the two still share some common features. For instance, in both periods violence created and affirmed identities and status roles. A tale by Franco Sacchetti (d. c. 1400) relates the case of a Florentine judge, who, unable to pay a certain fine, was imprisoned at Le Stinche. The newcomer was greeted by a veteran inmate, Massaleo degli Albizzi, facetiously described as 'a new man with many new indulgences'. Massaleo looked after the judge, invited him to share his dinner, and, observing that his protégé had yet to arrange for a bed, offered to make room in his own - a proposal which the judge, rather unwisely, accepted. During his first night in prison, the 'fish' was torn from his sleep by Massaleo's intimate stroking:

'But, what are you doing to it?'

'Forgive me, I thought it was mine!'

The incident became the cause of much laughter, and the story concludes as the judge, having forgiven his friend's 'innocent mistake', finds a new bed to sleep in. ${ }^{30}$

Behind the tale's homoerotic humour lie the emotional distress and the unnerving realities of prison life: a new place, with new social rules. The protagonist's ordeal is reminiscent of a common rite of passage, still prevalent in prisons today. ${ }^{31}$ Its purpose was simple and its timing precise. As Sacchetti put it, in molesting his guest Massaleo was moved 'more by indulgence than by vice'. Perhaps, then, the veteran inmate was testing the newcomer in order to impose status divisions (patron/protégé) and allocate sexual roles (superordinate/subordinate; active/passive). Whatever the case may be, modern prison observers and inmates would agree that the judge's response was crucial in shaping his prison career ${ }^{32} \mathrm{Had}$ he allowed himself to be terrorized into homosexual intercourse, for instance, 
he would have been branded as weak - by all accounts a ruinous tag in prison: regardless of his status outside the walls, any claim he might have had to authority would have vanished. In his instinctive naïvete the judge seems to have avoided a miserable existence by a hair's breadth.

The judge's response came at a price, though. The tale's conclusion reveals, casually but unmistakably, a tragic aftermath. The protagonist is henceforth described as 'a possessed man' - an expression suggesting a drastic mental deterioration. The story ends on this very note, employing the past tense to underscore how the judge permanently occupied his new bed: 'and in that [bed], while he remained in prison, he slept' ${ }^{3}{ }^{33}$ Such reactions were not rare, at least as literary tropes. In another prison tale set in 1410, the protagonist is described as 'dozy on account of the melancholy and discomfort [or embarrassment] of being in prison ${ }^{34}$ Mild depression and other forms of emotional withdrawal such as constant sleeping are recognized today as characteristic (albeit reversible) behaviours of newly arrived inmates, and this may have been the import of the above descriptions. ${ }^{35}$ Thus, such tales capture key dimensions of the violent encounter with prison life, underscored by mental solitude and social disconnection among inmates whom present-day observers have variously described as 'little islands in a dead sea' or 'atoms interacting in confusion'. ${ }^{36}$

Violence or its threat was instrumental in creating or reaffirming identity, status, and sexual roles. In this sense, medieval inmates and their free contemporaries shared similar cultural values. For physical brutality permeated late-medieval urban society, with its proclivity to violence and vendetta ${ }^{37}$ As in the world at large, aggression in prison and the general violation of its rules were ways to contest public order. As such these behavioural patterns can be viewed as part of a more or less implicit daily struggle against officialdom: an attempt to assert oneself, emerge from anonymity, and 'beat the system'. However, it is also plausible that alongside this species of political consciousness, violence and the infraction of prison rules were underwritten by boredom.

\section{SEMI-EXCLUSIVENESS / SEMI-INCLUSIVENESS}

Judging from the available data from Le Stinche's records, it seems that the supervisors' charter serves as a better barometer of inmate dissidence than the actual reports it prefaced. Still - to push the metaphor a little further - no storm was in sight, for the mercury's rate of decline remained slow. As mentioned, the tumultuous annals of fourteenth-century Italy contain not a single instance in which urban rulers repressed an inmate riot independently of external political unrest. Considering their prisons' 
small staffs and physical permeability, urban magistrates were fairly successful in reducing the risk of concerted inmate violence. To do so they employed two methods, however unconsciously or unsystematically. The first was to dissociate prison personnel from the execution of corporal punishments or legal torture. ${ }^{38}$ However, such a policy was not universal: Bolognese prison guards could augment their salaries by flogging convicts and by carrying out dismemberments and even capital punishments; in Arras, a hangman was a permanent and rather busy member of the prison staff. $^{39}$

But a second, more common, and probably more efficient method to avoid incurring the inmates' wrath was to create a sufficiently tolerable environment - and what partly rendered medieval incarceration tolerable was the prisoners' maintenance of ties with the outside world. The human ebb and flow of prisons was not the fruit of neglect, oversight, or corruption; it was essential to the prison's routine. In the absence of a kitchen, as was the case in Florence and Venice, families, charitable individuals, and confraternity officials fed the inmates regularly. In Bologna, where meals were available but costly, poor prisoners had to rely on a lay friar for their daily bread. Family members and other individuals could offer medical and legal aid, at least prior to the foundation of sickrooms and the nomination of public advocates. In Florence, arguably the most self-sufficient of medieval prisons, mass was held regularly at the internal chapel, but elsewhere communion and confession depended on visiting friars and priests. The inmates and staff's reliance on a constant interaction with the outside world meant that access to prisoners was monitored but not restricted; only under exceptional circumstances did inmates resort to pleading for visitation rights. ${ }^{40}$

Among the pains of modern imprisonment, severing the ties with the outside world is widely considered not only the harshest but also the most deleterious for both the prisoner and his or her family. Conversely, social psychologists have emphasized time and again the negative relation between the availability of outside contact and inmate violations of the prison's behavioural code. ${ }^{41}$ North American convicts today are eligible on average for one monthly visit that lasts thirty minutes - provided, of course, that they maintain their visiting privileges and that their families can afford the long and often costly trip. ${ }^{42}$ Accordingly, and given the sometimes extortionate rates of obligatory reversed-charge calls from prison, a convict's main (and apart from his or her TV set, often sole) representative of the free world is the guard, who in a sense is no less a prisoner. The outcome, it is argued, is a polarized and antagonistic view of society, which for many is translated into an obstacle to reintegration and a catalyst for antisocial prison behaviour. Prison reformers have thus 
reiterated the need to liberalize visitation procedures and increase the inmates' exposure to members of society at large, including, in the case of male convicts, women. By contrast, medieval incarceration was premised on regular access to the outside world. ${ }^{43}$

Not all modern studies conclude in favour of convicts' maintaining intimate ties with the extramural world or increasing their exposure to it. Yet if it is not a panacea for recidivism, there is a growing consensus that structured engagement with free society, as part of 'meaningful daytime activity', is likely to reduce the pains of imprisonment, curb antisocial behaviour in prison, and facilitate a smoother transition into life at large. ${ }^{44}$ As we have seen, the semi-inclusive nature of medieval incarceration obviated total social seclusion. And while the permeable walls of medieval institutions did not necessarily reduce violence within and crime outside, at least they enabled prisoners to remain in daily touch with their families, friends, spiritual guides, and professional associates. True, there were certain negative, even dangerous, ramifications to such access, from smuggling weapons to trafficking prostitutes to potential threats against convicts' antagonists on the outside; it is also worth considering that an inmate's proximity and access to his or her family and friends may have exacerbated, rather than diminished, the distress of separation. Still, as I now move to show, the advantages of outside access appear to have outweighed its shortcomings.

\section{GAUGING TOLERABILITY}

Modern scholars employ three basic parameters to evaluate the relative tolerability or harshness of the prison environment: average periods of captivity, inmate mortality (whether from disease, injury, or, especially, suicide), and the frequency of escapes. ${ }^{45}$

By and large, most late-medieval inmates left the prison behind after paying their imposed fine or debt or having completed their original or modified sentences, which were relatively brief. According to the extant registers of Le Stinche from the second half of the fourteenth century, between 38 and 53 per cent of the inmates were released within six months. Of those whose incarceration crossed into the next administrative term, between 70 and 82 per cent were set free within the next six months (see Figure 2). Notwithstanding the lower life expectancies of medieval urban populations, these typical durations fall short of modern criminologists' definition of long-term imprisonment, currently averaging two and a half years. ${ }^{46}$

Deaths in prison were fairly infrequent. And were it not for famine, plagues, and political altercations-and these were rampant in the 


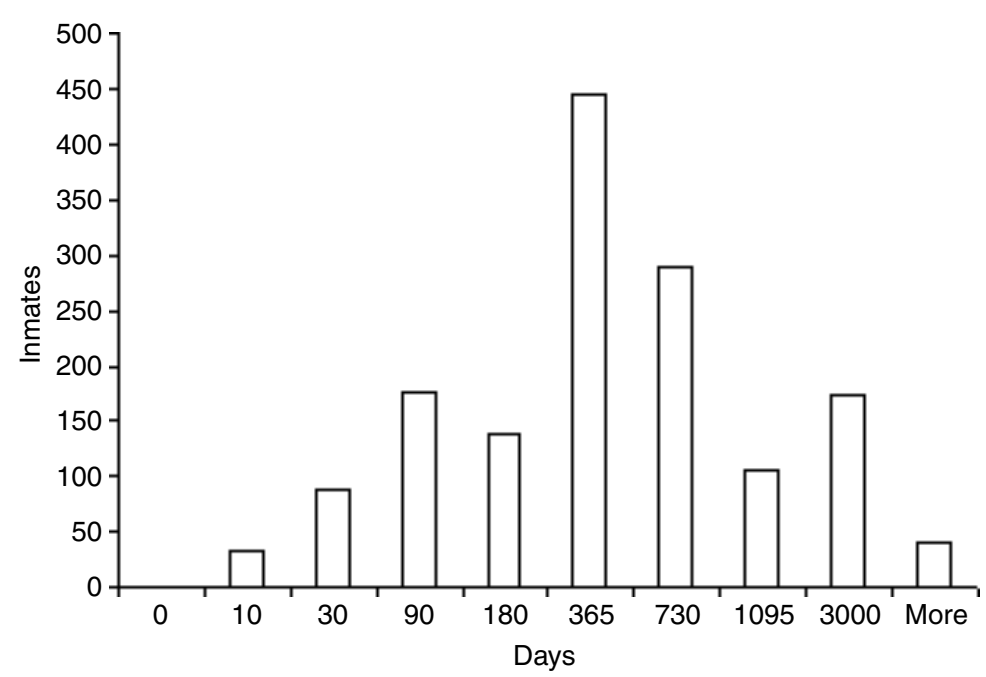

Figure 2. Periods of incarceration at Le Stinche (1347-1396). (Source: State Archives of Florence, SS Car. 82-5, 88-91.)

fourteenth century - the number of inmates who died while incarcerated would have been lower still. The figure of 60 mortalities within two years cited in 1327 by the petitioners for a new prison in Siena is anomalous, as is the reported loss of 22 inmates there during January and February $1340 .{ }^{47}$ By contrast, between 1332 and 1387 only 7 prisoners are reported to have died at Venice; the first wave of the Black Death (1347-1348), which decimated Europe's population within several months, struck down a mere 25 of Le Stinche's inmates and, during a less eventful semester, that prison's notary reported a total of 3 deaths. ${ }^{48}$ Most importantly, there is no indication that any of these casualties was the result of suicide or self-injury. And although such incidents were periodically reported in England and France, ${ }^{49}$ they never approached their startling current rates of at least five times higher than in free society. ${ }^{50}$

At first blush, escapes were surprisingly infrequent. The poet Francesco Berni (1497/8-1535) would have us believe that the late-medieval prison was literally a 'factory' for escapes: 'There you can hear the noise of hammers, / Of picks, and of beams [working] to send / Free anyone into this place or the other. ${ }^{51}$ The description is apt, considering that prison walls were usually weak, low, and poorly guarded. Moreover, as we have seen, access to the outside world was frequent and the personnel were notoriously corruptible: the threat of an enormous fine for aiding an 
escape often proved to be an insufficient deterrent for these modestly paid officials. Given all this, escape attempts were strikingly rare: virtually no escapes are recorded at the Arras prison in the first half of the fourteenth century; in Florence, only seven escapes took place between 1299 and 1344; and in Venice, for which our records are fuller than elsewhere on the matter, a mere thirteen failed and successful attempts are recorded for the period between 1316 and $1393 .{ }^{52}$

Such relatively low rates were due in part to the inmate's options once outside. A successful escape only begins by leaving the prison; how to survive beyond its walls is a different challenge altogether. The anonymity of the modern metropolis, the availability of transportation, and easy access to long-distance communications were not characteristic of medieval urban centres. A convict on the run had to remain in hiding - an near-impossible feat given the scale of even the largest medieval city - or else flee - a choice that was impractical for men without considerable means. More than today, life on the run in the middle ages meant a very precarious freedom, and few were willing or able to make this sacrifice. Berni's verses, in short, were an exercise in wishful thinking: the prison's invisible walls were a more powerful deterrent than its physical ones. ${ }^{53}$

But while an inmate's limited chances of survival on the outside may have acted as a deterring force, the tolerability of medieval prison life was no less instrumental. To borrow a term from modern demography, there was little to 'push' or to 'pull' the prisoner from his or her cell: social ties with the outside world were substantial, conditions at least temporarily bearable, and liberty often at hand. Strategies for coping in prison were premised on these expectations. Although violence appears to have been common in its various forms, the inmates' greatest suffering seems to have been boredom, a predicament conveniently met by gambling, the most widely documented infraction of medieval prison regulations.

\section{CONCLUSION}

The semi-inclusive character of medieval prison life, however unintended, had various implications. Chief among these, at least in terms of the inmates' welfare, was the maintenance of ties with the outside world. Prisoners situated at the physical centre of the city, within earshot of government officials, neighbours, friends, and relatives, and in constant interaction with them, could expect a reasonable degree of protection from major abuses. But access to free society (including formal supervision) alleviated only some pains of imprisonment; others, such as 
intra-inmate violence, general boredom, and poverty remained inherent in this proto-total institution, with its crowded wards, corruptible staff, and lack of structured time.

Inmates sought to alleviate their pains through a range of banned pursuits. Notable among these was gambling, whose flexibility and familiarity accommodated many of the constraints of clandestine prison activities. At the same time, there is ample evidence of inmate violence and sexual promiscuity, all of which served different functions in different contexts. Sexual molestation, for instance, could have created or reaffirmed status (as when an inmate first walked into a new ward), but it could equally have provided a distraction from monotony.

In pursuing and concealing these forbidden pleasures, inmates were occasionally aided by the prison staff. The rationale for such collusion has been hypothesized above as one involving a correlation between the interests of captors and captives. This overlap, in turn, may help explain the massive underreporting of infractions of rules to the prison's supervisors and the near-total lack of complaints by inmates about guards. Thus, despite its relative openness to the ouside world, the medieval prison community jointly perpetuated a culture of deception in order to maintain certain release-valves for the benefit of both inmates and staff. This equilibrium between accessibility and deception, alongside the inmates' relatively short periods of incarceration, allowed prison life in the middle ages to be a tolerable experience by the inmates' own criteria and certainly by modern estimates.

The disparity between medieval and modern prison experiences should not diminish or distract us from the attempt to understand the former in the latter's terms, as I hope to have shown. On the other hand, making presentist arguments on the basis of medieval (and often incommensurable) evidence is riskier. What this study can offer historians, penologists, and sociologists of the modern prison concerns the relation between inmate coping and social accountability, specifically how the latter's presence or absence may determine whether convicts (and institutionalized deviants generally) become marginal or altogether liminal people. The distinction is not merely semantic, since it carries major implications for inmates' adaptation to prison life and their capacity for readjustment once at large.

As I noted previously, the key difference between marginal and liminal people is that the former are perched between social exclusion and inclusion, while the latter are written out of social memory, even if temporarily. ${ }^{54}$ 'Being remembered' - that is, being treated as a member of a given society - is accompanied by certain expectations. It is thus no coincidence that among modern inmates' greatest anxieties is to feel 
unimportant: bored and unproductive, lacking influence and dignity ${ }^{55}$ In a sense, their fear is of being pushed from marginality into liminality, of being warehoused and then forgotten. ${ }^{56}$ Medieval inmates' relative visibility and accessibility seem to have rendered such a process unlikely, above all since inmates' presence promoted accountability among the extramural society.

Accountability cut both ways. Modern sociologists tend to agree that 'prisonization', or the process of conforming to the alternative world of the prison, is, paradoxically, detrimental to an inmate's successful reintegration into society. ${ }^{57}$ As one prison reformer famously put it, 'You cannot train a man for freedom under conditions of captivity. ${ }^{58}$ Infusing the prison environment with external norms, whether through involving local residents in prison programming, opening local labour markets to inmates, or founding facilities largely based on a multifaceted interaction with the outside world, is widely considered to be effective in reducing prisonization and conducive to reintegration..$^{59}$ To be sure, such initiatives apply only to certain inmates and communities, and it seems that, given the compartmentalization of modern metropolises, beneficial and well-monitored access is mostly possible among medium-scale rural communities. ${ }^{60}$ Nonetheless, the steady ruralization of prisons, especially in the US (but increasingly in Britain and elsewhere), fails to meet the desired standards of their location, ${ }^{61}$ a prerequisite for accessibility, interaction, and the espousal of accountability. These are crucial factors if modern inmates are to remain marginal rather than slip into liminality.

\section{ACKNOWLEDGEMENTS}

This article substantially augments and revises G. Geltner, The medieval prison: a social history (Princeton, 2008), especially chapter three. Research was conducted in the state archives of Bologna (hereafter ASB), Florence (ASF), Lucca (ASL), Parma (ASPa), Pisa (ASPi), Siena (ASS), and Venice (ASV). Most of the archival series cited below are minutes (deliberazioni), decrees (riformagioni e provvigioni), and sentences (sentenze e bandi) of a city's governing body, which could also function as a court. Also cited are urban statutes (statuti) and records produced by individual officials such as the Podestà, Capitano del Popolo, and (in Florence) the Esecutore, who had their own courts and functionaries. Unless otherwise noted, translations are the author's, and dates have been modernized. Special thanks to Seena Fazel and Jeff Schwegman for their comments on an earlier draft and to Yad Hanadiv and Lincoln College for their support.

\section{ENDNOTES}

1 The society of captives: a study of a maximum security prison (Princeton, 1958), 79.

2 Robert Johnson and Hans Toch eds., The pains of imprisonment (Beverly Hills, 1982); Edward Zamble and Frank J. Porporino, Coping, behavior and adaptation in prison 
inmates (New York, 1988); Alison Liebling and Shadd Maruna eds., The effects of imprisonment (Portland, 2005).

3 Michel Foucault, Discipline and punish: the birth of the prison, trans. Alan Sheridan (New York, 1979), 160. A 'total institution' was seminally defined by Erving Goffman, in Asylums: essays on the social situation of mental patients and other inmates (Garden City, NY, 1961), xiii, as 'a place of residence and work where a large number of like-situated individuals, cut off from the wider society for an appreciable period of time, together lead an enclosed, formally administered round of life'.

4 On medieval incarceration see Martino Beltrani-Scalia, Sul governo e sulla riforma delle carceri in Italia: saggio storico e teorico (Turin, 1868), 211-348; A. Bertoletti, 'Prigioni e prigioneri in Mantova dal secolo XIII al secolo XIX', Bullettino ufficiale della Direzione Generale delle Carceri 17 (1887), 51-70, 163-82; Louis Batiffol, 'Le Châtelet de Paris vers 1400', Revue Historique 61-63 (1896-1897), 225-64; 225-35; 42-55, 266-83; Gotthold Bohne, Die Freiheitsstrafe in den italienischen Stadtrechten des 12.-16. Jahrhunderts, 2 vols. (Leipzig, 1922-1925); Roger Grand, 'La prison et la notion d'emprisonnement dans l'ancien droit', Revue Historique de Droit Français et Étranger, 4th ser., 19-20 (1940-1941), 58-87; Annik Porteau-Bitker, 'L'emprisonnement dans le droit laïque du moyen âge', Revue Historique de Droit Francais et Étranger 46 (1968), 211-45, 398-428; Ralph B. Pugh, Imprisonment in medieval England (Cambridge, 1968); Mirielle Vincent-Cassy, 'Prison et châtiments à la fin du Moyen Âge', in Les marginaux et les exclus dans l'histoire (Paris, 1979), 262-74; Nicole Gonthier, 'Prisons et prisonniers à Lyon aux XIVe et XVe siècles', Mémoires de la Société pour l'Histoire du Droit et des Institutions des Anciens Pays Bourguignons, Comtois et Romands 39 (1982), 15-30; Carola M. Small, 'Prisoners at the Castellany of Artois in the early fourteenth century', Histoire Sociale - Social History 26 (1993), 345-72; Halina Manikowska, 'The Florentine communal prison - Le Stinche - in the fourteenth century', Acta Poloniae Historica 71 (1995), 133-60; Edward M. Peters, 'Prison before the prison: the ancient and medieval worlds', in The Oxford history of the prison: the practice of punishment in western society, ed. N. Morris and D. J. Rothman (Oxford, 1995), 3-43; James Given, Inquisition and medieval society: power, discipline and resistance in Languedoc (Ithaca and London, 1997); and Jean Dunbabin, Captivity and imprisonment in medieval Europe, 1000-1300 (New York, 2002).

5 Geltner, The medieval prison, esp. chapter two. On the ruralization and disguises of modern prisons see William G. Nagel, The new red barn: a critical look at the modern American prison (New York, 1973), 47-9; The Home Office, New directions in prison design: report of a Home Office study of new generation prisons in the U.S.A. (London, 1985), 8-19; Mike Davis, City of quartz: excavating the future of Los Angeles (New York, 1992), 253-7.

6 See respectively Ginevra Niccolini di Camugliano, The chronicles of a Florentine family, 1200-1470 (London, 1933), 48; Paola Foschi, 'I palazzi del Comune di Bologna nel Duecento', in Bologna: Re Enzo e il suo mito: atti della Giornata di studio, 11 giugno 2000, ed. Antonio Ivan Pini and Anna Laura Trombetti Budriesi (Bologna, 2001), 94-100; ASS, Consiglio Generale [=CG], Deliberazioni [=Del.] 104, fols. 43r-44v (17 February 1327); ASF, Provvisioni, Registri 26, 118 (12 November 1333); and H. Moranvillé, 'Note sur les prisons à la fin du XIVe siècle', Bulletin de la Société d'Histoire de Paris 21 (1894), 74.

7 Geltner, The medieval prison, chapter three. For modern parallels in Brazil and Indonesia see respectively Drauzio Varella, Estação Carandiru (Sao Paolo, 1999), and Sujinah, In a Jakarta prison: life stories of women inmates, trans. Irfan Kortschak (Jakarta, 2000), passim. 
8 Victor W. Turner, The ritual process: structure and anti-structure (Chicago, 1969), 95, and 'Variations on a theme of liminality', in Secular ritual, ed. Sally F. Moore and Barbara G. Meyerhoff (Assen/Amsterdam, 1977), 36-52.

9 See Edward Sagarin, Deviants and deviancy (New York, 1975); David Downes and Paul Rock, Understanding deviance, 5th edn (Oxford, 2007).

10 Respectively, Lapo Mazzei, Lettere di un notaro a un mercante del secolo XIV con altre lettere e documenti, ed. Cesare Guasti, 2 vols. (Florence, 1880), 1:61, 2:343; N. Tommaseo, Della bellezza educatrice (Venice, 1838), 313; Curzio Mazzi ed., Il Burchiello: saggio di studi sulla sua vita e sulla sua poesia (Bologna, 1879), 69; Domenico M. Manni, Le veglie piacevoli, 2nd edn, 8 vols. (Florence, 1815-1816), 2:38; Lodovico Frati and Albano Sorbelli eds., Matthaei de Griffonibus memoriale historicum de rebus bononiensium (Città di Castello, 1902), 65-6. Literate activity in Venice is documented in Ferruccio Zago ed., Consiglio dei Dieci: deliberazioni miste, 3 vols. (Venice, 1962-1993) [=X Zago], Reg. VI, no. 570 (3:117). And see Maria Luisa Meneghetti, 'Scrivere in carcere nel medioevo', in Studi di filologia e letteratura italiani in onore di Maria Picchio Simonelli, ed. Pietro Frassica (Alessandria, 1993), 185-99; René Menage, 'Deux poètes en prison: Maître Jean Régnier e le prisonnier desconforté de Loches', in Exclus et systemes d'exclusion dans la litterature et la civilisation médiévales (Aix-en-Provence, 1978), 239-49; and Linne F. Mooney and Mary-Jo Arn eds., The Kingis Quair and other prison poems (Kalamazoo, MI, 2005).

11 C. D. Hassler ed., Fratris Felicis Fabri Evagatorium in Terrae Sanctae, Arabiae et Egypti Peregrinationem, 3 vols. (Stuttgart, 1843-1849), 2:409-10.

12 Five hundred years of Venetian prison graffiti are being documented by Prof. Giandomenico Romanelli, Director of the Musei Civici di Venezia.

13 ASF, Atti dell'Escutore degli Ordinamenti di Giustizia $[=A E]$ 501, fols. 14v (11 May 1367), 18v-19r (2 July 1367); 538, fols. 4v-5r (19 May 1368); 540, fol. 21v (4 April 1368) (this series contains the protocols of Le Stinche's supervisors); ASF, Soprastanti alle Stinche [=SS], Entrata e Uscita [=EU] 382, fol. 4r (30 October 1367); 388, fol. 1r (4 October 1376) (this is the prison's financial archive); X Zago, Reg. VI, nos. 406 (3:89), 443-5 (3:95), 599 (3:121); ASV, Maggior Consiglio, Deliberazioni [=MC Delib.] 20 (Liber Novella), fol. 404v (6 June 1382).

14 Ludovico Zdekauer, 'Il gioco in Italia nei secoli XIII e XIV e specialmente in Firenze', Archivio Storico Italiano, 4th ser., 18 (1886), 20-74; 19 (1887), 3-22; Gherardo Ortalli ed., Gioco e giustizia nell'Italia di Comune (Treviso, 1993); Franco Sacchetti, Il trecentonovelle, ed. Emilio Faccioli (Turin, 1970), LXXXI (208-10). For archival documentation see below.

15 ASF, Statuti 1355, L. I, R. LIV, fol. 45v.

16 ASF, $A E$ 489, fol. 12r-v (27 November 1366); 538, fols. 19v-20r (29 August 1368); 674, fol. 32r (4 March 1373).

17 ASV, Avogaria di Comun [=AC] 3644, Reg. 1, fol. 8v (27 October 1378).

18 Albert K. Cohen et al. eds., Prison violence (Lexington, 1976); Johnson and Toch eds., The pains of imprisonment, 63-93; Richard Sparks et al., Prisons and the problem of order (Oxford, 1996); Edgar Kimmett et al., Prison violence: the dynamics of conflict, fear and power (Cullompton, 2003); Peter L. Nacci and Thomas R. Kane, 'The incidence of sex and sexual aggression in Federal prisons', Federal Probation 47 (1983), 31-6; Michael C. Braswell et al. eds., Prison violence in America, 2nd edn (Cincinnati, 1994); Desmond Ellis et al., 'Violence in prisons: a sociological analysis', American Journal of Sociology 80 (1974), 16-43. On inmate dissidence generally see Roy D. King and Kathleen McDermott, "My geranium is subversive": some notes on the management of trouble in prisons', The British Journal of Sociology 41 (1990), 445-71. 
19 See ASB, Curia del Podestà, Corona ed Armi, b. 29, Reg. 1332II (20 August 1322); ASF, Provvisioni, Registri 33, fols. 6v-7r (9 June 1344), respectively, and see Villani, Nuova cronica, XIII, xvii, ed. Giuseppe Porta, 3 vols. (Parma, 1990-1991), 3:333-4. According to Brian R. Carniello ('The rise of an administrative elite in medieval Bologna: notaries and popular government, 1282-1292', Journal of Medieval History 28 (2002), 344-5 and n. 94), prison notaries were hard to recruit on account of their fear of violence. But there is little evidence to support their concern.

20 Compare ASF, $A E 129$ (1349; the earliest surviving charter) and $A E 489$ (1366) or any subsequent register until 1400 .

21 ASF, $A E$ 1401, fol. 3r (7 May 1400): 'irato animo et malo modo multas et varias rissas ac rumores et percussiones, tam manu vacuis quam cum ferro, videlicet percutiendo et vulnerendo unus alterum'.

22 See Lee H. Bowker, Prison victimization (New York, 1980).

23 ASL, AnzianFi avanti la libertà 2, fol. 63 (17 September, 1330): 'ne ipsi carcerati ultra debitum et convenientum modum graventur, vel contra eos fieri aliqua extortio, intolerabilis iniqua vel iniusta'. And see ASPa, Comune 10, fols. 31v-32r (1 December 1388), 65v-67v (4 July 1395); 36, fols. 5v-6r (3 November 1317), 14r (1 October 1323?).

24 For the prison's ground plan see Becchi, Sulle Stinche di Firenze e su'nuovi edifizi eretti in quel luogo (Florence, 1839), pl. II. A reconstruction is in Geltner, The medieval prison, Appendix 3.

25 ASF, $A E$ 573, fol. 18r (26 March 1369).

26 Respectively, ASV, MC Delib., 20 (Liber Novella), fol. 404v (6 June 1382); ASL, Sentenze e bandi 7, unnumbered fols. (5 April 1337); and Statuta Communis Parmae ab anno MCCLXVI ad circiter MCCCIV (Parma, 1857), 174.

27 Emilio Paolo Vicini ed., Respublica Mutinensis (1306-1307), 2 vols. (Milan, 1929-1932), $1: 185$.

28 ASF, $A E$ 148, fol. 22v (23 July 1350).

29 For Venice see Antonino Lombardo ed., Le deliberazioni del Consiglio dei XL della Repubblica di Venezia, 3 vols. (Venice, 1957-1967), Reg. 22, nos. 129-33 (1:36-7), Reg. 25, no. 54 (3:18), and X Zago, Reg. V, nos. 405-6, 448-9 (3:157, 169-71). For Bologna see ASB, Governo [=Gov.], Riformagioni e Provvigioni [=RP], Riformagioni del Consiglio del Popolo e della Massa $[=C P M]$ 221, fol. 50v (5 September 1321); RP, Riformagioni e Provvigioni (serie cartacea) 225, Reg. 49, fol. 103v (1 April 1333); Pod. Corone ed Armi, b. 3, Reg. 3, fol. 32r (29 August, 1291); b. 18, Reg. 4, fols. 79r-80r (27 August, 1310); b. 28, Reg. 1332II, fol. 27r (20 August 1322); Ufficio dei Memoriali 101, fol. 502r (January 1301). For Florence see ASF, Riformagioni e Provvigioni $[=R P]$ 19, 59 (18 March 1323), fols. 82r-83r; 20, 33 (12 December 1323), fol. 47r-v; 27, 173 (26 April 1334), fol. 108r-v; 27, 142 (26 July 1336), fols. 65v-66r. For Siena see ASS, $C G$ Del. 106, fols. 120v-122v (27 December 1328). See also Gonthier, 'Prisons et prisonniers à Lyon', 20.

30 Sacchetti, Il trecentonovelle, CXXXIX (361-2).

31 Marek M. Kaminski, Games prisoners play: the tragicomic worlds of Polish prison (Princeton, 2004), 41-6, 134-8. And see Victor F. Nelson, Prison days and nights (Boston, 1933), 158-60, 164-5; Piri Thomas, Down these mean streets (New York, 1967), 267; Edward Buckner, The animal factory (New York, 1977), 12; Jack Henry Abbott, In the belly of the beast: letters from prison (London, 1982), 79; Jimmy A. Lerner, You got nothing coming: notes from a prison fish (New York, 2002), 152-6.

32 Joseph F. Fishman, Sex in prison: revealing sex conditions in American prisons (London, 1935), 83-5; Esther Hefferman, Making it in prison: the square, the cool, and the life (New York, 1972), 92-7; Wayne S. Wooden and Jay Parker, Men behind bars: sexual 
exploitation in prison (New York and London, 1982), 1-3, 74-6, 91-2, 101-20; Hans Toch, Living in prison: the sociology of survival (New York, 1977), 50-7; Katy Richmond, 'Fear of homosexuality and modes of rationalisation in male prisons', The Australian and New Zealand Journal of Sociology 14 (1978), 51-7; Anne Applebaum, Gulag: a history of the Soviet camps (London, 2003), 288-9, 482.

33 Sacchetti, Il trecentonovelle, CXXXIX (362).

34 Michele Barbi ed., Novella del grasso legnaiuolo nella relazione di codice Palatino 200 (Florence, 1968), 140.

35 Robert M. Lindner, Stone walls and men (New York, 1946), 420-1; Harold Garfinkel, 'Conditions of successful degradation ceremonies', American Journal of Sociology 61 (1956), 420-4; John J. Gibbs, 'The first cut is the deepest: psychological breakdown and survival in the detention setting', in Johnson and Toch eds., The pains of imprisonment, 97-114; Zamble and Porporino, Coping, behavior and adaptation, 76-91.

36 Respectively, Goffman, Asylums, 69-70, and Donald Clemmer, The prison community (New York, 1958), 297.

37 David Herlihy, 'Some psychological and social roots of violence in the Tuscan cities', in Lauro Martines ed., Violence and civil disorder in Italian cities, 1200-1500 (Berkeley, 1972), 129-54; Jacques Heers, Le clan familial au Moyen Age: étude sur les structures politiques et sociales des milieux urbains (Paris, 1974); Daniel Lord Smail, 'Common violence: vengeance and inquisition in fourteenth-century Marseilles', Past \& Present 151 (1996), 29-59; Trevor Dean, 'Marriage and mutilation: vendetta in late medieval Italy', Past \& Present 157 (1997), 3-36; Andrea Zorzi, 'La cultura della vendetta nel conflitto politico in età comunale', in Le storie e la memoria: in onore di Arnold Esch (Florence, 2002), 135-70; Claude Gauvard, Violence et ordre public au moyen age (Paris, 2005). See also David Nirenberg, Communities of violence: persecution of minorities in the middle ages (Princeton, 1996); and Wolfgang Sofsky, Saggio sulla violenza, trans. Barbara Trapani and Luca Lamberti (Turin, 1998).

38 Dunbabin, Captivity and imprisonment, 42-3.

39 ASB, Curia del Podestà, Sindacato, Reg. 1286 I/1, fol. 31r (28 March 1286). And see Hermann U. Kantorowicz, Albertus Gandinus und das Strafrecht der Scholastik (Berlin, 1907), nos. 44, 134 (270-7, 367-70). On Arras, see Small, 'Prisoners at the Castellany of Artois', 351, 365-6.

40 For individual and institutional charity see ASPi, Provvisioni e consigli 99, fols. 9v-10r (1 July 1332); A. Grion ed., 'La "Legenda" del B. Venturino da Bergamo secondo il testo inedito del codice di Cividale', Bergomum, n.s. 30 (1956), 46, 71; Augustine Thompson, Cities of God: the religion of the Italian communes, 1125-1325 (University Park, PA, 2005), 106, 195; Félix Aubert, 'Le parlement et les prisonniers', Bulletin de la société d'histoire de Paris 20 (1893), 103; Daniel Waley, Siena and the Sienese in the thirteenth century (Cambridge, 1991), 143; Moranville, 'Note sur les prisons', 73; Gonthier, 'Prisons et prisonniers à Lyon', 22; Small, 'Prisoners at the Castellany of Artois', 351-2.

41 Toch, Living in prison, 52-6; Ann Cordilia, The making of an inmate: prison as a way of life (Cambridge, MA, 1983), 31-46; Ulla V. Bondesson, Prisoners in prison societies (New Brunswick, NJ and Oxford, 1989), 158-9. On incarceration's impact on family life see Pauline Morris, Prisoners and their families (London, 1965); Jill Matthews, Forgotten victims: how prison affects the family (London, 1983); Roger Shaw, Children of imprisoned fathers (London, 1987), and Prisoners' children: what are the issues? (London and New York, 1993).

42 Human Rights Watch, Prison conditions in the United States (New York, 1991), 58-60. In the course of one year, 41 per cent of the Trenton inmates studied by Sykes 
(The society of captives, 65) received not a single visitor. Visitations rates in 1980s Canada, as tracked by Zamble and Porporino (Coping, behavior and adaptation, 81-2), are marginally higher.

43 George Devereux and Malcolm C. Moos, 'The social structure of prisons, and the organic tensions', Journal of Criminal Psychopathology 4 (1942), 306-24; Lloyd W. McCorckle and Richard Corn, 'Resocialization within walls', Annals of the American Academy of Political and Social Sciences 293 (1954), 95-6; Stanton Wheeler, 'Socialization in correctional communities', American Sociological Review 26 (1961), 697-8; Mary Koscheski et al., 'Consensual sexual behavior', in Christopher Hensely ed., Prison sex: practice and policy (Boulder and London, 2002), 111-31; Chairmian Blackler, 'Primary recidivism in adult men: differences between men on first and second prison sentence', British Journal of Criminology 8 (1966), 130-69; Mike Fitzgerald, 'The telephone rings: long-term imprisonment', in Anthony E. Bottoms and Roy Light eds., Long-term imprisonment (Aldershot, 1987), 142-57; Sheila R. Lochhead, Outside in: a study of prison visiting (York, 1993), 26-33.

44 Liberalization of visitations is endorsed by George Saleebey in The non-prison: a new approach to treating youthful offenders (Milwaukee, 1970), 20-4, and critiqued by Joseph James Lembo in 'The relationship of institutional disciplinary infractions and the inmate's personal contact with the outside community', Criminologica $\mathbf{5 0}$ (1969-70), 50-4, and by Ruth Jamieson and Adrian Grounds in 'Release and adjustment: perspectives from studies of wrongly convicted and politically motivated prisoners', in Liebling and Maruna eds., The effects of imprisonment, 41-2. And see M. Leese et al., 'An ecological study of factors associated with rates of self-inflicted death in prison in England and Wales', International Journal of Law and Psychiatry 29 (2006), 355-60.

45 P. A. Banister et al., 'Psychological correlates of long-term imprisonment, I-II', British Journal of Criminology 13 (1973), 312-30; John Gunn et al., Psychiatric aspects of imprisonment (London, 1978); Lee H. Bukstel and Peter R. Kilman, 'Psychological effects of imprisonment on confined individuals', Psychological Bulletin 88 (1980), 469-93; James Bonta and Paul Gendreau, 'Reexamining the cruel and unusual punishment of prison life', Law and Human Behavior 14 (1990), 347-72; Seena Fazel and John Danesh, 'Serious mental disorder in 23000 prisoners: a systematic review of 62 surveys', The Lancet 359 (2002), 545-50; Seena Fazel and Ram Benning, 'Natural deaths in male prisoners: a 20-year mortality study', The European Journal of Public Health 16 (2006), 441-4.

46 Joan Petersilia, When prisoners come home: parole and prisoner reentry (Oxford, 2003), 3; and see Timothy J. Flanagan ed., Long-term imprisonment: policy, science and correctional practice (Thousand Oaks, CA, 1995), 3-9, and Liebling and Maruna, The effects of imprisonment, 1-32.

47 ASS, CG Del. 104, fols. 43r-44v (17 February 1327); and Agnolo di Tura del Grasso (attributed), Cronaca maggiore, in Cronache senesi, ed. Alessandro Lisini and Fabio Iacometti (Bologna, 1933-1935), 526.

48 For Venice see ASV, AC 3641, fols. 112r (22 January 1332), 173r (4 September 1337); 3642, fol. 49v (3 March 1343); 3644, Reg. 1, fols. 22v-23r (13 September 1380), 41r-v (21 April 1382), 78v (16 August 1385), Reg. 2, fol. $11 \mathrm{r}$ (30 January 1387). For Florence see ASF, SS Car. 82, 91. Small ('Prisoners at the Castellany of Artois', 365) notes only two casualties at Arras in the first half of the fourteenth century. Death rates in English prisons were higher, according to Pugh, Imprisonment in medieval England, 331, and H. S. Bennett, The Pastons and their England: studies in an age of transition (Cambridge, 1968), 175-6. 
49 Alexander Murray, Suicide in the middle ages, 3 vols. (Oxford and New York, 1998-), 1:154-60, 185-91, 295-304.

50 Seena Fazel et al., 'Suicide in male prisons in England and Wales, 1978-2003', The Lancet 366 (2005), 1301-2, is the most systematic study to date. And see Alison Liebling, Suicides in prison (London and New York, 1992); Nicolas Bourgoin, Le suicide en prison (Paris, 1994); Alison Liebling and Tony Ward eds., Deaths in custody: international perspectives (Bournemouth, 1994); Roger Matthews, Doing time: an introduction to the sociology of imprisonment (Basingstoke and London, 1999), 69-72; Hans Toch, Men in crisis: human breakdowns in prison (Chicago, 1975), 127-43; and Bruce L. Danto ed., Jail house blues: studies of suicidal behavior in jail and prison (Orchard Lake, 1973).

51 Il primo libro del l'opere burlesche di M. Francesco Berni (edited anonymously; Florence, 1552), fol. 53r.

52 Small, 'Prisoners at the Castellany of Artois', 364, and Geltner, The medieval prison, chapter three. According to Walter L. Wakefield ('Friar Ferrier, inquisition at Caunes, and escapes from prison at Carcassone', Catholic History Review 58 (1972), 220-37), escapes from the royal prison at Carcassone were rare, despite allegedly harsh conditions. According to Pugh (Imprisonment in medieval England, 219-24), escapes from English prisons were more common.

53 See Smail, 'Common violence', 48. According to Applebaum (Gulag, 355-70), some Soviet governors relied on the mere reputation of the Russian wilderness to keep prisoners at bay, never bothering to surround their camps with a fence.

54 Turner, The ritual process, 95, and 'Variations on a theme of liminality', 36-52.

55 Alison Liebling (assisted by Helen Arnold), Prisons and their moral performance: a study of values, quality, and prison life (Oxford, 2004), 432.

56 Mark S. Fleisher, Warehousing violence (Newbury Park, 1989); Löic Wacquant, Deadly symbiosis: the rise of neoliberal penalty (Oxford, 2003).

57 'Prisonization' was originally coined by Clemmer (The prison community, 300). See also Wheeler, 'Socialization in correctional communities', 697-712.

58 Sir Alexander Paterson, member of the UK Prison Commission between 1922 and 1947, quoted in Howard Jones et al., Open prisons (London, 1977), 5.

59 See above, nn. 43-4.

60 James B. Jacobs, New perspectives on prisons and imprisonment (Ithaca and London, 1983), 99-106; Nick Flynn, 'Resettlement prisons: fulfilling the Prison Service National Statement of Purpose' (London, 1996).

61 Leslie Fairweather, 'Psychological effects of the prison environment', in Leslie Fairweather and Seán McConville eds., Prison architecture: policy, design and experience (Oxford, 2000), 34. 